\title{
OPTIMASI WAKTU DAN SUHU KALSINASI TEPUNG CANGKANG RAJUNGAN (Portunus sp.) SEBAGAI BAHAN BAKU HIDROKSIAPATIT
}

\section{The Optimization of Time and Temperature to Calcine The Crab Shell (Portunus sp.) Powder as Raw Material of Hydroxyapatite}

\author{
Bagus Hadiwinata $^{1 *}$, Fera Roswita Dewi ${ }^{2}$, Dina Fransiska ${ }^{2}$, dan Niken Dharmayanti ${ }^{3}$ \\ ${ }^{1}$ Sekolah Usaha Perikanan Menengah Negeri Kotaagung, \\ Jl. Pantai Harapan, Ds. Way Gelang, Lampung, 35384, Indonesia \\ ${ }^{2}$ Balai Besar Riset Pengolahan Produk dan Bioteknologi Kelautan dan Perikanan, \\ JI. KS Tubun, Petamburan VI, Jakarta Pusat, DKI Jakarta, 10260, Indonesia \\ ${ }^{3}$ Politeknik Ahli Usaha Perikanan, JI. Raya Pasar Minggu, Jakarta Selatan, DKI Jakarta, 12520, Indonesia \\ *Korespondensi penulis : bagushadiwinatams@gmail.com,
}

Diterima: 1 Februari 2021; Direvisi: 13 April 2021; Disetujui: 11 Juni 2021

\begin{abstract}
ABSTRAK
Kalsinasi merupakan salah satu tahapan penting dalam sintesis hidroksiapatit, karena kemurnian tepung $\mathrm{CaO}$ sangat tergantung pada suhu dan waktu kalsinasi. Penelitian ini bertujuan untuk mendapatkan waktu dan suhu optimum pada kalsinasi tepung cangkang rajungan (Portunus sp.) pada pembuatan tepung kalsium oksida $(\mathrm{CaO})$. Pada penelitian ini, cangkang rajungan dikalsinasi pada suhu 700 dan $800^{\circ} \mathrm{C}$ selama 4 dan 5 jam. Hasil penelitian menunjukkan bahwa perlakuan suhu dan waktu kalsinasi berpengaruh terhadap rendemen, jumlah massa kalsium, dan karbon dari tepung $\mathrm{CaO}(p<0,05)$. Sedangkan jumlah massa fosfor dan oksida tidak dipengaruhi oleh perlakuan kalsinasi $(p>0,05)$. Tepung $\mathrm{CaO}$ kemudian diidentifikasi gugus fungsi, morfologi, komposisi, dan kristalinitasnya menggunakan Fourier Transform Infrared Spectroscopy (FTIR), Scanning Electron Microscope (SEM) dengan Energy Dispersive Spectroscopy (EDS), dan $X$-Ray Diffraction (XRD). Hasil pengamatan menunjukan tepung $\mathrm{CaO}$ terbaik diperoleh dari perlakuan kalsinasi pada suhu $800^{\circ} \mathrm{C}$ selama 5 jam, menghasilkan morfologi tepung dengan ukuran yang lebih seragam serta pori-pori yang lebih halus dan lebih kecil dibandingkan perlakuan lainnya. Selain itu, kadar kalsium dan derajat kristalinitas yang dihasilkan pada perlakuan tersebut lebih besar dibandingkan dengan perlakukan lainnya, yaitu berturut-turut $91,96 \pm 5,07 \%$ dan $75 \%$. Dengan demikian dapat disimpulkan bahwa proses kalsinasi pada suhu $800^{\circ} \mathrm{C}$ selama 5 jam menghasilkan tepung $\mathrm{CaO}$ yang paling optimum dan dapat dijadikan bahan baku sintesis hidroksiapatit.
\end{abstract}

KATA KUNCI : cangkang rajungan, kalsinasi, tepung $\mathrm{CaO}$, hidrokisapatit

\begin{abstract}
Calcination is one of the important steps in the synthesis of hydroxyapatite because the purity of $\mathrm{CaO}$ powder is highly dependent on the temperature and time of calcination. This study aimed to optimize the time and temperature of calcination on the production of Portunus $s p$. calcium oxide (CaO) powder. In this study, crab shells were calcined at 700 and $800^{\circ} \mathrm{C}$ for 4 and 5 hours. The results showed that the temperature and time of calcination affected the yield, total mass of calcium, and carbon of $\mathrm{CaO}$ powder $(p<0.05)$. Meanwhile, the mass amount of phosphor and oxide was not affected by the calcination treatment $(p>0.05)$. The CaO powder was identified its functional groups, morphology, composition, and crystallinity using Fourier Transform Infrared Spectroscopy (FTIR), Scanning Electron Microscope (SEM) with Energy Dispersive Spectroscopy (EDS), and X-Ray Diffraction (XRD), respectively. The results showed the best CaO powder was obtained from the calcination treatment at a temperature of $800^{\circ} \mathrm{C}$ for 5 hours. The CaO morphology was uniform in size, finer, and smaller pores than that of other treatments. In addition, the calcium content and degree of crystallinity produced by this treatment were greater than other treatments, i.e. $91.96 \pm 5.07 \%$ and $75 \%$, respectively. It can be concluded that the calcination process at $800^{\circ} \mathrm{C}$ for 5 hours produces the best $\mathrm{CaO}$ powder and can be used as raw material for the synthesis of hydroxyapatite.
\end{abstract}

KEYWORDS: crab shell, calcination, CaO powder, hydroxyapatite 


\section{PENDAHULUAN}

Cangkang rajungan merupakan hasil samping pengolahan rajungan yang belum optimal pemanfaatannya. Industri pengolahan rajungan di Indonesia memanfaatkan $30,07 \%$ sampai $42,1 \%$ bagian rajungan untuk diambil dagingnya, terutama untuk produk kaleng (Suharto, Romadhon, \& Redjeki, 2016). Sekitar 50\% cangkang rajungan menjadi limbah dan dilaporkan memiliki kandungan kalsium karbonat $\left(\mathrm{CaCO}_{3}\right)$ sekitar 40 sampai $70 \%$ (Suharto et al., 2016) yang dapat dimanfaatkan sebagai kalsium pada sintesis hidroksiapatit (Raya, Mayasari, Yahya, Syahrul, \& Latunra, 2015). Tingginya kandungan kalsium karbonat menjadikan cangkang rajungan memiliki potensi untuk diekstrak kalsiumnya menjadi bahan baku hidroksiapatit dalam negeri.

Hidroksiapatit merupakan anggota mineral apatit yang mengandung hidroksida dengan rumus kimia $\mathrm{Ca}_{10}\left(\mathrm{PO}_{4}\right)_{6}(\mathrm{OH})_{2}$ (Ngapa, 2018), serta memiliki kadar basa mendekati netral sebagai komponen utama jaringan tulang yang bersifat rapuh (Yang et al., 2014). Produksi hidroksiapatit dalam negeri masih sangat kurang, sehingga Indonesia masih harus mengimpor dengan harga Rp. 1,5 miliar per $5 \mathrm{mg}$ untuk perancah tulang (Henggu, Ibrahim, \& Suptijah, 2019). Pada bidang farmasi, hidroksiapatit berfungsi sebagai drug delivery system, yaitu media penghantar obat melalui strukturnya yang berpori (Bose, Tarafder, Edgington, \& Bandyopadhyay, 2011).

Hidroksiapatit juga dapat berfungsi sebagai anti kanker pada penyakit kanker tulang, yaitu untuk memperbaiki tulang yang terkikis serta mengisi jaringan tulang yang hilang (Kolmas, Krukowski, Laskus, \& Jurkitewicz, 2016). Hidroksiapatit dapat diaplikasikan sebagai biokeramik yang kontak dengan jaringan tulang (bone tissue) dan sebagai pelapis (coating) pada implan tulang (Harahap \& Helwani, 2015). Hidroksiapatit juga bermanfaat sebagai pasta injectable bone substitute (IBS) yang disintesis dengan radiasi dan dapat digunakan sebagai graft biomaterial (Warastuti \& Abbas, 2011).

Untuk menjadi hidroksiapatit, cangkang rajungan perlu diproses menjadi tepung kalsium oksida $(\mathrm{CaO})$ terlebih dahulu guna menghilangkan unsur karbonat pada $\mathrm{CaCO}_{3}$. Keberadaan karbonat harus didekomposisi karena akan menghambat pembentukan hidroksiapatit. Proses dekomposisi tersebut berguna untuk menghasilkan tepung $\mathrm{CaO}$ dengan kandungan kalsium tinggi (Khoirudin, Yelmida, \& Zultiniar, 2015). Tepung $\mathrm{CaO}$ merupakan salah satu prekursor kalsium pada sintesis hidroksiapatit. $\mathrm{CaO}$ direaksikan dengan fosfor sehingga membentuk rasio kalsium dan fosfor $(\mathrm{Ca} / \mathrm{P})$ yang diinginkan. Salah satu kriteria hidroksiapatit yang baik adalah rasio $\mathrm{Ca} / \mathrm{P}$ sebesar 1,67 (Kantharia et al., 2014). Oleh karena itu perlu dilakukan optimasi pada proses pengolahan cangkang rajungan menjadi tepung $\mathrm{CaO}$ untuk mendapatkan tepung $\mathrm{CaO}$ dengan karakteristik yang diinginkan.

Kalsinasi merupakan proses untuk melepaskan unsur-unsur karbonat pada cangkang rajungan. Proses kalsinasi dapat dilakukan pada suhu $500-700^{\circ} \mathrm{C}$ untuk temperatur rendah, $700-900^{\circ} \mathrm{C}$ untuk temperatur sedang, dan $>900^{\circ} \mathrm{C}$ untuk temperatur tinggi (Handayani, Zuhrayani, Putri, \& Nanda, 2020). Keberhasilan proses kalsinasi cangkang rajungan dapat dipengaruhi oleh karakteristik bahan baku, temperatur, dan waktu kalsinasi. Pada penelitian cangkang rajungan sebelumnya telah dilakukan kalsinasi $\mathrm{CaO}$ dengan suhu $1.000^{\circ} \mathrm{C}$ selama 3 jam, tetapi belum diketahui bagaimana karakteristik kalsium, gugus fungsi yang terbentuk, serta derajat kristalinitasnya (Rizkayanti \& Yusuf, 2019).

Saat ini, belum ada penelitian yang menjelaskan hasil tepung $\mathrm{CaO}$ dari cangkang rajungan dengan pemakaian suhu sedang. Penelitian ini melakukan kalsinasi tepung cangkang rajungan dengan suhu sedang, yaitu $700^{\circ} \mathrm{C}$ selama 4 dan 5 jam, serta $800^{\circ} \mathrm{C}$ selama 4 dan 5 jam. Selanjutnya dilakukan analisis karakteristik tepung $\mathrm{CaO}$ dari cangkang rajungan, dengan perlakuan suhu kalsinasi pada kategori sedang dengan waktu berbeda. Tujuannya adalah untuk mendapatkan tepung $\mathrm{CaO}$ dengan karakteristik terbaik dengan melihat parameter pendukung sebagai bahan dasar hidroksiapatit.

\section{BAHAN DAN METODE}

\section{Bahan}

Bahan utama yang dipakai pada penelitian ini adalah cangkang rajungan (Portunus sp.) yang berasal dari unit pengolahan rajungan di TPI Pasir Putih, Karawang, Jawa Barat. Cangkang rajungan semi basah dikemas dalam karung untuk kemudian diangkut pada suhu $3-5^{\circ} \mathrm{C}$ menuju Balai Besar Riset Pengolahan Produk dan Bioteknologi Kelautan dan Perikanan (BBRP2B-KP) di Jakarta.

\section{Metode}

Tahapan kalsinasi cangkang rajungan mengacu pada metode Rizkayanti dan Yusuf (2019). Cangkang rajungan semi basah dicuci menggunakan air bersih segera setelah sampai di laboratorium untuk membersihkan kotoran dan sisa daging dengan menyikat cangkang kemudian dibilas kembali dengan air bersih. Cangkang yang telah bersih dijemur hingga kering selama 2 hari. Cangkang kering selanjutnya 
dihancurkan dengan blender HR2106 (Philips) dengan kecepatan $30 \mathrm{rpm}$. Hancuran cangkang kemudian disaring dengan saringan plastik berukuran 100 mesh. Cangkang rajungan yang sudah disaring kemudian dianalisis kandungan proksimatnya yang meliputi kadar air (BSN, 2006a), lemak (BSN, 2006b), protein (BSN, 2006c), dan abu (BSN, 2010).

Tepung cangkang rajungan dikalsinasi dalam furnace 6000 (barnstead, USA) pada suhu 700 dan $800^{\circ} \mathrm{C}$ selama 4 dan 5 jam. Setelah kalsinasi, suhu furnace diturunkan sampai $300^{\circ} \mathrm{C}$, selanjutnya dimatikan, dan tepung $\mathrm{CaO}$ dibiarkan dalam furnace selama $5 \mathrm{jam}$. Tepung $\mathrm{CaO}$ yang dihasilkan kemudian dipindahkan ke dalam desikator dan didiamkan selama 3 jam. Selanjutnya dilakukan perhitungan rendemen tepung $\mathrm{CaO}$, analisis gugus fungsi, derajat kristalinitas, morfologi, kadar kalsium, fosfor, oksida, serta karbon. Rendemen dihitung dengan membandingkan berat tepung $\mathrm{CaO}$ dengan tepung cangkang rajungan kering sebelum proses kalsinasi.

\section{Analisis gugus fungsi}

Analisis gugus fungsi dilakukan menggunakan instrumen Spectrum One FTIR (Fourier Transform Infrared Spectroscopy) seri C69526 (Perkin Elmer) yang mampu membaca pada bilangan gelombang $4.000-400 \mathrm{~cm}^{-1}$ dengan resolusi $4 \mathrm{~cm}^{-1}$. Sebelum dilakukan analisis gugus fungsi, sampel dipeletkan dengan $\mathrm{KBr}$. Sebanyak $2 \mathrm{mg}$ sampel dicampur dengan $\mathrm{KBr}$ pada perbandingan 1/100 kemudian dibuat pelet dengan tekanan 7 ton selama 15 menit. Spektrum yang dihasilkan dianalisis gugus fungsinya berdasarkan Warastuti dan Abbas (2011).

\section{Analisis morfologi}

Morfologi tepung $\mathrm{CaO}$ dianalisis menggunakan instrumen SEM (Scanning Electron Microscopy). Tepung $\mathrm{CaO}$ diambil secara swab kemudian dilakukan proses pelapisan (coating) dengan logam emas ( $\mathrm{Au}$ ) selama 1 menit. Mikrostruktur tepung $\mathrm{CaO}$ diamati menggunakan software JEOL 6000 serta didokumentasikan gambarnya dengan perbesaran hingga 1000 kali. Proses pengukuran dilakukan pada akselerasi tegangan $20 \mathrm{kV}$.

Analisis persentase kalsium, fosfor, karbon, dan oksida

Analisis komposisi kalsium, fosfor, dan oksida dilakukan menggunakan SEM yang dilengkapi EDS (Energy Dispersive Spectroscopy) untuk menentukan persentase kadar kalsium, fosfor, dan oksida. Tepung $\mathrm{CaO}$ diambil secara swab, diletakkan pada plat sampel (sample holder), lalu diamati menggunakan software JEOL 6000 pada perbesaran 1000 kali. Proses pengukuran dilakukan pada akselerasi tegangan 20 kV. Selanjutnya dilakukan analisis terhadap persentase kalsium, fosfor, dan oksida mengacu pada metode Anitha dan Pandya (2014). Jumlah massa hasil perhitungan oleh software dijadikan dasar dalam perhitungan persentase kadar kalsium, fosfor, karbon, dan oksida.

\section{Analisis derajat kristalinitas}

Analisis kristalinitas tepung $\mathrm{CaO}$ dilakukan dengan metode kuantitatif menggunakan instrumen $X$-ray Difraction tipe Rigaku Smartlab. Perhitungan kristalinitas dilakukan dengan rumus yang digunakan oleh Landi, Tampieri, Celotti, dan Spriro (2000) dalam hasil penelitian Purwasasmita dan Gultom (2008) sebagai berikut:

$\%$ Kristalinitas $=1-[(\mathrm{V} 110-\mid 300) / / 300] \times 100 \%$ dimana:

V110-I300 = puncak terrendah antara puncak hasil difraksi 112 dan 300

1300

$$
=\text { intensitas puncak yang dihasilkan }
$$
V300

\section{Analisis statistik}

Penelitian ini menggunakan rancangan percobaan dengan 4 perlakuan dan 2 ulangan proses. Untuk melihat pengaruh perlakuan terhadap rendemen, serta jumlah kadar kalsium, fosfor, karbon, dan oksida, dilakukan analysis of varian (ANOVA) oneway menggunakan aplikasi SPSS seri 23 (SPSS Inc., Chicago, III, USA). Selanjutnya, terhadap parameter perlakuan yang berbeda nyata dilakukan uji lanjut Tukey.

\section{HASIL DAN PEMBAHASAN}

\section{Kandungan Proksimat Cangkang Rajungan}

Hasil pengujian proksimat cangkang rajungan menunjukkan kadar air 7,36 $\pm 0,001 \%$; abu $63,12 \pm 0,004 \%$; lemak $1,28 \pm 0,004 \%$, dan protein $13,18 \pm 0,01 \%$. Kadar abu cangkang rajungan pada penelitian ini menunjukkan prosentase yang paling besar diantara parameter proksimat lainnya. Hal ini selaras dengan hasil penelitian Lubena, Naidir, Andrian, dan Sandi, (2020) yang menyatakan bahwa cangkang rajungan mengandung abu $44,03 \%$, protein $29,91 \%$, dan air $0,45 \%$. Tingginya kadar abu pada cangkang rajungan menandakan kandungan mineral yang tinggi.

Menurut Kusumaningrum, Sutono, dan Pamungkas (2016) semakin besar kadar abu pada tulang ikan dibandingkan kadar proteinnya, maka tulang tersebut semakin keras dan memiliki 
kandungan mineral yang tinggi. Tinginya kandungan mineral pada cangkang rajungan mengindikasikan bahwa bahan alam ini berpotensi sebagai tepung kalsium oksida $(\mathrm{CaO})$. Kalsium dari cangkang rajungan ini berpotensi sebagai bubuk hidroksiapatit dengan menambahkan prekursor fosfor. Hidroksiapatit merupakan anggota mineral apatit yang terdiri atas prekursor kalsium dan fosfor (Ngapa, 2018).

\section{Kenampakan Tepung $\mathrm{CaO}$ Cangkang Rajungan}

Proses kalsinasi dengan suhu dan waktu berbeda menghasilkan kenampakan tepung $\mathrm{CaO}$ yang berbeda (Gambar 1). Tepung $\mathrm{CaO}$ dari perlakuan suhu $700^{\circ} \mathrm{C}$ selama 4 jam memiliki kenampakan yang belum seragam, yaitu berwarna putih kehitaman. Selain itu, tekstur tepung $\mathrm{CaO}$ masih kasar dan belum sepenuhnya menjadi abu, sedangkan perlakuan suhu $700^{\circ} \mathrm{C}$ selama 5 jam menghasilkan kenampakan tepung $\mathrm{CaO}$ hampir seluruhnya putih, tetapi masih ada cangkang yang berwarna kehitaman. Tepung $\mathrm{CaO}$ pada perlakuan suhu $800^{\circ} \mathrm{C}$ selama 4 jam telah menjadi putih sedikit kemerahan. Selanjutnya, pada saat dikalsinasi 5 jam, tekstur tepung $\mathrm{CaO}$ sudah sangat halus dan mulai menunjukkan warna putih seragam.

Menurut Rosalina, Pascawinata, dan Roesnoer (2017), warna tepung $\mathrm{CaO}$ setelah kalsinasi yang berwarna hitam menandakan dekomposisi matriks organik seperti protein dan kolagen tidak sempurna. Sementara itu, warna putih $\mathrm{CaO}$ menandakan sebaliknya, yaitu dekomposisi matriks organik yang sempurna (Rosalina et al., 2017). Berdasarkan morfologi hasil kalsinasi tepung $\mathrm{CaO}$, maka perlakuan $800^{\circ} \mathrm{C}$ selama 5 jam merupakan kondisi kalsinasi optimum yang menghasilkan tepung $\mathrm{CaO}$ dengan warna putih dan tekstur halus.

\section{Rendemen Tepung $\mathrm{CaO}$}

Secara umum, perlakuan kalsinasi berpengaruh terhadap rendemen tepung $\mathrm{CaO}$ (Tabel 1). Hasil analisis lanjutan uji Tukey menunjukkan perlakuan
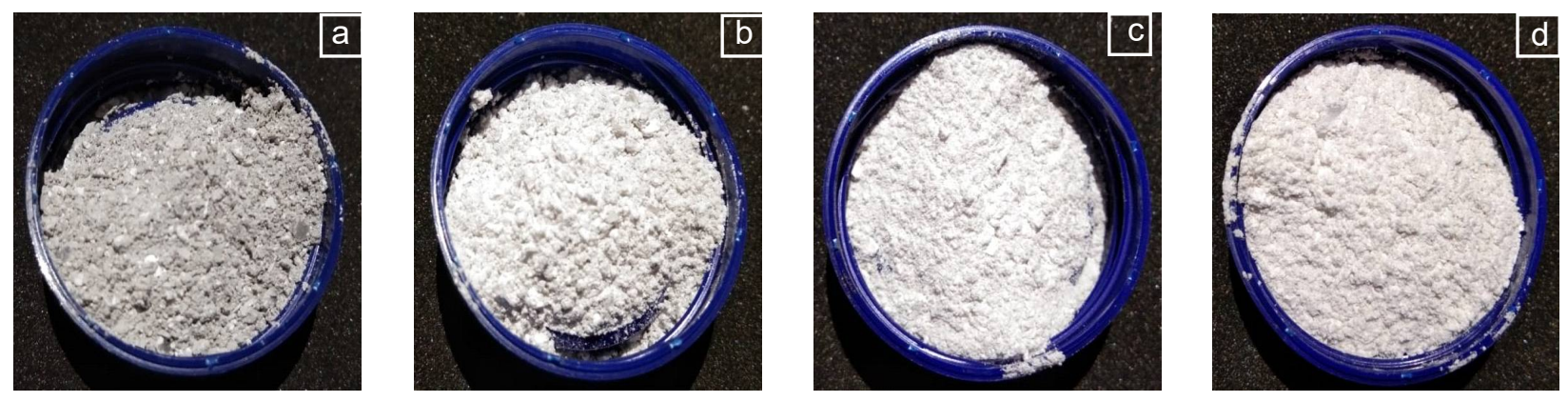

Gambar 1. Tepung $\mathrm{CaO}$ hasil kalsinasi tepung cangkang rajungan pada berbagai perlakuan suhu dan waktu kalsinasi; a. Perlakuan kalsinasi $700^{\circ} \mathrm{C}$ selama 4 jam, b. $700^{\circ} \mathrm{C}$ selama 5 jam, c. $800^{\circ} \mathrm{C}$ selama 4 jam, d. $800^{\circ} \mathrm{C}$ selama 5 jam

Figure 1. CaO powder from calcination of crab shell powder with temperature and time variation; a. calcination treatments of $700^{\circ} \mathrm{C}$ for 4 hours, b. $700^{\circ} \mathrm{C}$ for 5 hours, $c .800^{\circ} \mathrm{C}$ for 4 hours, $d .800^{\circ} \mathrm{C}$ for 5 hours

Tabel 1. Rendemen tepung $\mathrm{CaO}$ cangkang rajungan

Table 1. Yield of crab shell $\mathrm{CaO}$ powder

\begin{tabular}{ccc}
\hline \multicolumn{2}{c}{ Kalsinasi/Calcination } & Rendemen/Yield (\%) \\
\hline Waktu/Time (Jam/Hours) & Suhu/Temperature $\left({ }^{\circ} \mathrm{C}\right)$ & \\
\hline 4 & 700 & $62.10 \pm 0.71^{\mathrm{a}}$ \\
5 & 700 & $60.07 \pm 0.06^{\mathrm{b}}$ \\
5 & 800 & $43.38 \pm 0.14^{\mathrm{c}}$ \\
& 800 & $41.68 \pm 0.02^{\mathrm{c}}$ \\
\hline
\end{tabular}

Keterangan/Note: $\mathrm{n}=8(\mathrm{n}$ per proses $=2 / n$ per process $=2$ )

Notasi yang berbeda menunjukan perbedaan yang siginifikan terhadap perlakuan/Different superscripts label denotes significant difference across treatments 
antara suhu $700^{\circ} \mathrm{C}$ selama 4 jam dan 5 jam menghasilkan rata-rata rendemen berbeda nyata dengan perlakuan lainnya $(p<0,05)$. Akan tetapi, antara perlakuan suhu $800^{\circ} \mathrm{C}$ selama 4 jam dengan 5 jam menghasilkan rendemen tidak berbeda nyata $(p>0,05)$.

Kalsinasi pada suhu $700^{\circ} \mathrm{C}$ selama 4 jam menghasilkan rendeman yang paling tinggi dibanding dengan perlakuan lainnya, sementara kalsinasi pada suhu $800^{\circ} \mathrm{C}$ selama 5 jam menghasilkan rendemen terendah. Rendahnya rendemen pada suhu $800^{\circ} \mathrm{C}$ terjadi karena semakin banyak karbon yang hilang dalam proses dekomposisi $\mathrm{CO}_{2}$. Semakin sedikit kandungan karbon dan komponen lain setelah proses kalsinasi, tepung $\mathrm{CaO}$ yang dihasilkan memiliki tingkat kemurnian yang semakin tinggi (Handayani et al., 2020).

\section{Karakteristik Gugus Fungsi Tepung $\mathrm{CaO}$ Cangkang Rajungan}

Hasil analisis gugus fungsi pada Gambar 2 menunjukan bahwa semua tepung $\mathrm{CaO}$ hasil perlakuan suhu dan waktu kalsinasi terdeteksi adanya gugus fosfor $\left(\mathrm{PO}_{4}^{3-}\right)$. Hal ini ditandai dengan adanya gugus fungsi fosfor pada bilangan gelombang 1000$1100 \mathrm{~cm}^{-1}$ (Riyanto \& Maddu, 2014). Pada perlakuan suhu $700^{\circ} \mathrm{C}$ selama 4 jam terdeteksi adanya gugus $\mathrm{PO}_{4}{ }^{3-}$ sebanyak tujuh lengkungan tajam pada gelombang 1089, 15 dan $1048,30 \mathrm{~cm}^{-1}$. Selanjutnya, pada perlakuan $700^{\circ} \mathrm{C}$ selama 5 jam masih terdapat tujuh lengkungan tajam, tetapi terjadi peningkatan pada gelombang $\mathrm{PO}_{4}{ }^{3-} 1089,85$ dan $1049,25 \mathrm{~cm}^{-1}$. Pada perlakuan $800^{\circ} \mathrm{C}$, lengkungan tajam gugus $\mathrm{PO}_{4}^{3-}$ berkurang menjadi empat. Berkurangnya lengkungan tajam menandakan bahwa kandungan fosfor pada tepung $\mathrm{CaO}$ berkurang. Keberadaan gugus fosfor menandakan bahwa tepung $\mathrm{CaO}$ dapat dijadikan bahan baku hidroksiapatit (Supangat \& Cahyaningrum, 2017).

Berdasarkan profil gugus fungsi terlihat bahwa tepung hasil kalsinasi masih mengandung karbonat $\left(\mathrm{CO}_{3}{ }^{2-}\right)$. Hal ini ditandai dengan munculnya gugus karbonat pada bilangan gelombang $1400-1500 \mathrm{~cm}^{-1}$ (Hanura, Trilaksani, \& Suptijah, 2017). Gugus $\mathrm{CO}_{3}^{2-}$ pada perlakuan $700^{\circ} \mathrm{C}$ selama 4 jam terdeteksi pada $1423,58 \mathrm{~cm}^{-1}$, dan 5 jam pada 1455,97 $\mathrm{cm}^{-1}$. Sedangkan pada perlakuan suhu $800^{\circ} \mathrm{C}$ selama 4 jam, gugus $\mathrm{CO}_{3}^{2-}$ muncul pada $1456,55 \mathrm{~cm}^{-1}$, dan yang 5 jam pada $1467,93 \mathrm{~cm}^{-1}$. Munculnya gugus fungsi $\mathrm{CO}_{3}{ }^{2-}$ pada tepung $\mathrm{CaO}$ dapat disebabkan adanya karbon dioksida dari udara bebas saat pengangkatan tepung $\mathrm{CaO}$ dari furnace ke desikator. Selain itu, pengerjaan di ruang terbuka dapat menyebabkan karbon dioksida masuk ke dalam tepung $\mathrm{CaO}$ (Kurniawan, Hartini, \& Cahyanti, 2019).

Hasil analisis gugus fungsi menunjukkan masih terdapat hidroksil $\left(\mathrm{OH}^{-}\right)$. Hal ini terlihat pada hasil perlakuan kalsinasi pada suhu $700^{\circ} \mathrm{C}$ selama 4 jam yang muncul pada 3746,$02 ; 3641,44$ dan 3435,77 $\mathrm{cm}^{-1}$. Sedangkan pada perlakuan 5 jam, gugus $\mathrm{OH}^{-}$ terlihat pada 3642,32 dan $2919,24 \mathrm{~cm}^{-1}$. Untuk perlakuan kalsinasi cangkang rajungan pada suhu $800^{\circ} \mathrm{C}$ selama 4 jam, gelombang $\mathrm{OH}^{-}$berada pada sekitar 3642,51 dan 3435,28 cm-1. Sedangkan pada waktu 5 jam gugus $\mathrm{OH}-$, muncul pada 3787,44 dan $3640,79 \mathrm{~cm}^{-1}$. Pada perlakuan $800^{\circ} \mathrm{C}$ selama $5 \mathrm{jam}$, terlihat lengkungan tajam pada gelombang 3640,79 $\mathrm{cm}^{-1}$. Hal ini menandakan bahwa pemanasan kurang sempurna dalam pelepasan $\mathrm{H}_{2} \mathrm{O}$. Dekomposisi $\mathrm{H}_{2} \mathrm{O}$ berjalan dengan baik ditandai dengan hilangnya lengkungan tajam pada gelombang $4000-3000 \mathrm{~cm}^{-1}$ (Sunardi, Irawati, \& Wianto, 2011). Masih adanya gugus $\mathrm{OH}^{-}$pada tepung $\mathrm{CaO}$ hasil penelitian ini kemungkinan juga dapat disebabkan penyimpanan tepung $\mathrm{CaO}$ yang terlalu lama di dalam furnace selama 5 jam setelah proses kalsinasi selesai.

\section{Morfologi Tepung $\mathrm{CaO}$}

Hasil analisis morfologi tepung $\mathrm{CaO}$ menunjukkan bahwa cangkang rajungan yang telah dikalsinasi membentuk algomerasi atau gumpalan (Gambar 3). Hal ini sesuai dengan hasil penelitian Ichsan, Helwani, dan Zultiniar (2015) yang menyatakan bahwa setelah proses kalsinasi, morfologi tepung $\mathrm{CaO}$ berbentuk gumpalan. Terdapat kesamaan antara Gambar 3a sampai 3c, tepung kalsium berbentuk gumpalan datar berpori serta masih terdapat granula yang tidak seragam dan kasar. Hal berbeda terlihat dari tepung $\mathrm{CaO}$ pada Gambar 3D, yaitu bentuk partikelnya halus dan tidak kasar . Halusnya partikel pada perlakuan suhu $800^{\circ} \mathrm{C}$ selama 5 jam dapat disebabkan tingginya suhu kalsinasi. Semakin tinggi suhu pemanasan, dapat menyebabkan pengecilan hingga penutupan pori-pori tepung, serta menghilangnya batas-batas dari granula tersebut (Kurniawan, Nizar, Rijal, Bagas, \& Setyarsih, 2014). Morfologi tepung $\mathrm{CaO}$ yang halus lebih aman untuk diaplikasikan pada manusia. Morfologi $\mathrm{CaO}$ yang kasar/tajam dapat menyebabkan peradangan hingga melukai jaringan pada tubuh sehingga berpotensi menyebabkan bahaya (Dorozhkin, 2010).

\section{Persentase Jumlah Massa Kalsium (Ca), Fosfor(P), dan Oksigen(O), dan Karbon (C) Tepung CaO Cangkang Rajungan}

Hasil analisis persentase jumlah massa kalsium, fosfor, oksigen, dan karbon tepung $\mathrm{CaO}$ dengan 

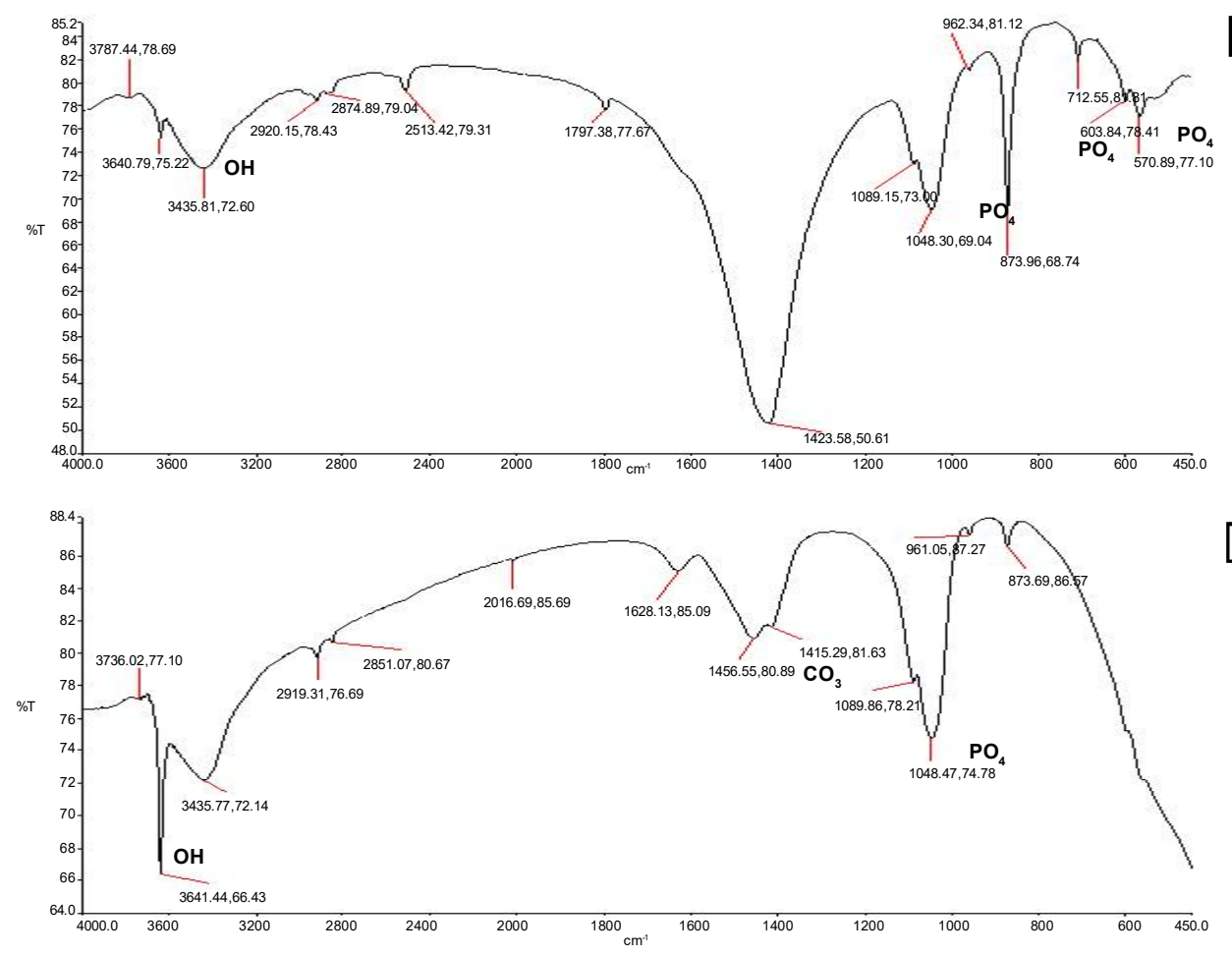

b
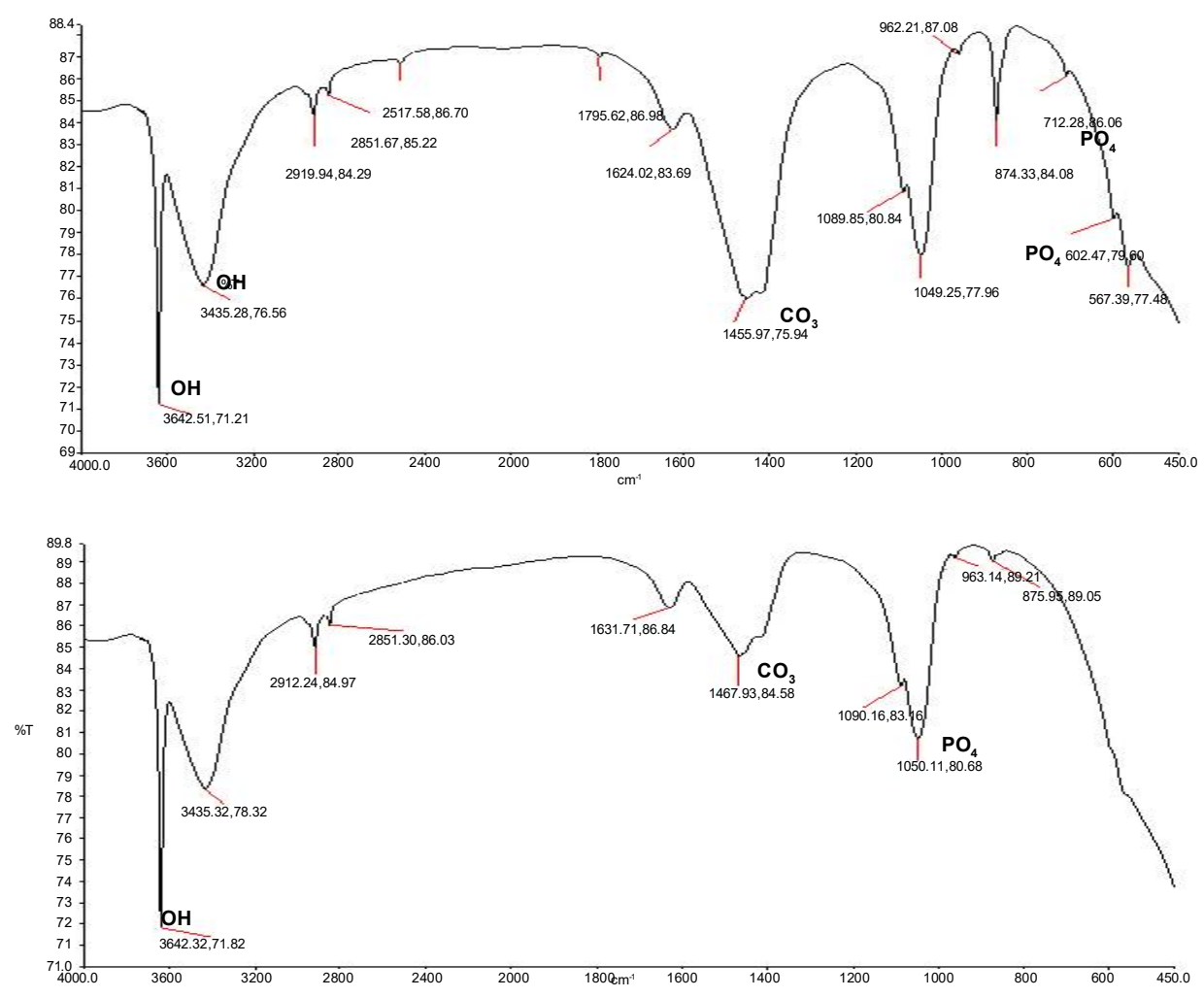

Gambar 2. Hasil analisis gugus fungsi tepung $\mathrm{CaO}$ cangkang rajungan pada berbagai perlakuan suhu dan waktu kalsinasi; a. Perlakuan kalsinasi $700^{\circ} \mathrm{C}$ selama 4 jam, b. $700^{\circ} \mathrm{C}$ selama 5 jam, c. $800^{\circ} \mathrm{C}$ selama 4 jam, d. $800^{\circ} \mathrm{C}$ selama 5 jam.

Figure 2. Results of functional groups analysis of $\mathrm{CaO}$ powder from crab shells with temperature and time variation; a. calcination treatments of $700^{\circ} \mathrm{C}$ for 4 hours, b. $700^{\circ} \mathrm{C}$ for 5 hours, $c$. $800^{\circ} \mathrm{C}$ for 4 hours, d. $800^{\circ} \mathrm{C}$ for 5 hours. 

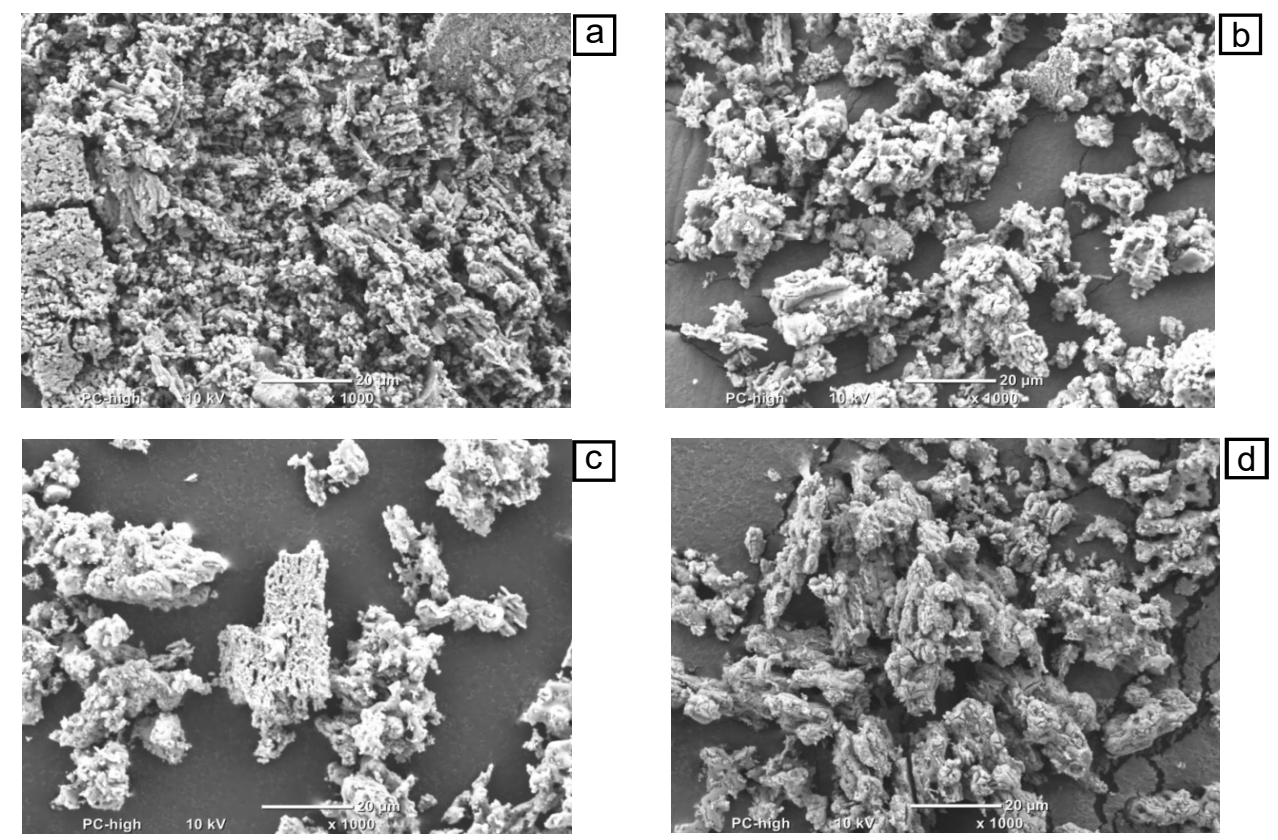

Gambar 3. Hasil analisis morfologi tepung $\mathrm{CaO}$ pada perlakuan suhu dan waktu kalsinasi; a. Perlakuan kalsinasi $700^{\circ} \mathrm{C}$ selama 4 jam, b. $700^{\circ} \mathrm{C}$ selama 5 jam, c. $800^{\circ} \mathrm{C}$ selama 4 jam, d. $800^{\circ} \mathrm{C}$ selama 5 jam.

Figure 3. Morphological analysis results of $\mathrm{CaO}$ powder with temperature and time variation; a. calcination treatments of $700^{\circ} \mathrm{C}$ for 4 hours, b. $700^{\circ} \mathrm{C}$ for 5 hours, $c .800^{\circ} \mathrm{C}$ for 4 hours, $d .800^{\circ} \mathrm{C}$ for 5 hours.

instrumen SEM dapat dilihat pada Tabel 2. Hasil analisa statistik menunjukan suhu dan waktu kalsinasi berpengaruh nyata pada jumlah massa kalsium tepung $\mathrm{CaO}(p<0,05)$. Akan tetapi, pada uji lanjut Tukey menunjukan bahwa jumlah massa kalsium tepung $\mathrm{CaO}$ pada perlakuan waktu pada suhu yang sama tidak berbeda nyata. Jumlah massa kalsium tepung $\mathrm{CaO}$ terkecil terdapat pada perlakuan $700^{\circ} \mathrm{C}$ selama 4 jam, sedangkan yang terbesar terdapat pada perlakuan $800^{\circ} \mathrm{C}$ selama 5 jam. Sebaliknya perlakuan suhu dan waktu kalsinasi tidak perpengaruh pada jumlah massa fosfor dan oksigen tepung $\mathrm{CaO}$. Perlakuan $800^{\circ} \mathrm{C}$ selama 4 jam menghasilkan tepung dengan fosfor terkecil, sedangkan perlakuan $700^{\circ} \mathrm{C}$ selama 5 jam menghasilkan fosfor tepung terbesar. Selanjutnya, jumlah massa oksigen tepung $\mathrm{CaO}$

Tabel 2 Persentase kandungan $\mathrm{Ca}, \mathrm{P}, \mathrm{O}$, dan $\mathrm{C}$ pada tepung $\mathrm{CaO}$ Table 2. Percentage of $\mathrm{Ca}, \mathrm{P}, \mathrm{O}$, and $\mathrm{C}$ of $\mathrm{CaO}$ powder

\begin{tabular}{cccccc}
\hline \multicolumn{2}{c}{ Kalsinasi/Calcination } & \multicolumn{3}{c}{ Kandungan Unsur/Element Content (\%) } \\
\hline $\begin{array}{c}\text { Waktu/Time } \\
(\text { Jam/Hours })\end{array}$ & $\begin{array}{c}\text { Suhu/ } \\
\begin{array}{c}\text { Semperature } \\
\left({ }^{\circ} \mathrm{C}\right)\end{array}\end{array}$ & $\begin{array}{c}\text { Kalsium/ } \\
\text { Calcium }\end{array}$ & $\begin{array}{c}\text { Fosforl } \\
\text { Phosphor }\end{array}$ & $\begin{array}{c}\text { Oksida/ } \\
\text { Oxide }\end{array}$ & $\begin{array}{c}\text { Karbon/ } \\
\text { Carbon }\end{array}$ \\
\hline 4 & 700 & $78.61 \pm 2.65^{\mathrm{a}}$ & $3.84 \pm 1.81^{\mathrm{a}}$ & $8.79 \pm 2.85^{\mathrm{a}}$ & $8.76 \pm 1.59^{\mathrm{a}}$ \\
5 & 700 & $80.36 \pm 1.31^{\mathrm{a}}$ & $5.12 \pm 2.04^{\mathrm{a}}$ & $6.60 \pm 0.52^{\mathrm{a}}$ & $4.33 \pm 0.19^{\mathrm{b}}$ \\
4 & 800 & $89.88 \pm 0.22^{\mathrm{b}}$ & $2.40 \pm 0.23^{\mathrm{a}}$ & $4.21 \pm 0.58^{\mathrm{a}}$ & $3.51 \pm 0.18^{\mathrm{b}}$ \\
5 & 800 & $91.96 \pm 2.93^{\mathrm{b}}$ & $5.09 \pm 1.57^{\mathrm{a}}$ & $2.63 \pm 0.73^{\mathrm{a}}$ & $3.14 \pm 0.86^{\mathrm{b}}$ \\
\hline
\end{tabular}

Keterangan/Notes:

Notasi yang berbeda menunjukan perbedaan yang siginifikan terhadap perlakuan/Different superscripts label denotes significant difference across treatments. 
terkecil terdapat pada perlakuan $800^{\circ} \mathrm{C}$ selama 5 jam, sedangkan perlakuan $700^{\circ} \mathrm{C}$ selama 4 jam menghasilkan jumlah oksigen tepung terbesar.

Jumlah massa karbon tepung $\mathrm{CaO}$ dipengaruhi oleh perlakuan kalsinasi $(p<0,05)$. Hasil uji lanjut menunjukkan perlakuan suhu $700^{\circ} \mathrm{C}$ selama 4 jam dengan perlakuan lainnya menghasilkan jumlah massa karbon yang berbeda nyata $(p<0,05)$, sedangkan antara perlakuan suhu $700^{\circ} \mathrm{C}$ selama 5 jam dengan $800^{\circ} \mathrm{C}$ selama 4 jam dan 5 jam menunjukkan jumlah massa karbon yang tidak berbeda nyata $(p>0,05)$. Jumlah karbon terbesar terdapat pada perlakuan $700^{\circ} \mathrm{C}$ selama 4 jam, sedangkan yang paling kecil pada perlakuan $800^{\circ} \mathrm{C}$ selama 5 jam. Berkurangnya jumlah massa karbon hasil kalsinasi menandakan pembakaran berjalan sempurna, dalam hal ini mendekomposisi kandungan karbon pada cangkang rajungan. Secara umum, kalsinasi merupakan proses pembakaran untuk mendekomposisi zat yang mudah terbakar, seperti karbon (Setiawan, 2016).

Berdasarkan hasil analisis EDS dapat disimpulkan bahwa perlakuan terbaik adalah kalsinasi pada suhu $800^{\circ} \mathrm{C}$ dengan waktu 5 jam, karena menghasilkan kadar kalsium yang terbesar. Tepung $\mathrm{CaO}$ ini kemudian dapat diolah lebih lanjut menjadi bubuk hidroksiapatit dengan dicampur prekursor fosfor. Fosfor jenis $\mathrm{H}_{3} \mathrm{PO}_{4}$ berfungsi untuk menambahkan kadar fosfor pada reaksi sintesis hidroksiapatit (Puspita \& Cahyaningrum, 2017).

\section{Persentase Derajat Kristalinitas Tepung $\mathrm{CaO}$ Cangkang Rajungan}

Hasil analisa kualitatif derajat kristalinitas terdapat pada Gambar 4. Hasil XRD menunjukan pola difraksi kristalinitas masih terdapat puncak yang melebar atau belum tajam. Hal tersebut menandakan tepung $\mathrm{CaO}$ yang diperoleh belum sempurna menjadi hidroksiapatit sehingga masih harus dilakukan pemanasan lanjutan. Selain itu, puncak yang melebar juga menandakan masih terdapat kontaminan lain pada saat proses kalsinasi. Tepung $\mathrm{CaO}$ dilaporkan memiliki gelombang kristalisasi yang lebar, dengan pemanasan lanjutan dapat diperoleh hidroksiapatit yang memiliki gelombang kristalinitas tajam (Negara \& Simpen, 2018).

Berdasarkan Tabel 3, derajat kristalinitas tepung $\mathrm{CaO}$ terendah terdapat pada perlakuan suhu $700^{\circ} \mathrm{C}$ selama 4 jam dengan nilai $64 \%$, sedangkan yang tertinggi ditunjukkan pada perlakuan suhu $800^{\circ} \mathrm{C}$ selama $5 \mathrm{jam}$, yaitu $75 \%$. Tepung $\mathrm{CaO}$ hasil perlakuan suhu $800^{\circ} \mathrm{C}$ selama 4 dan 5 jam dapat dikategorikan

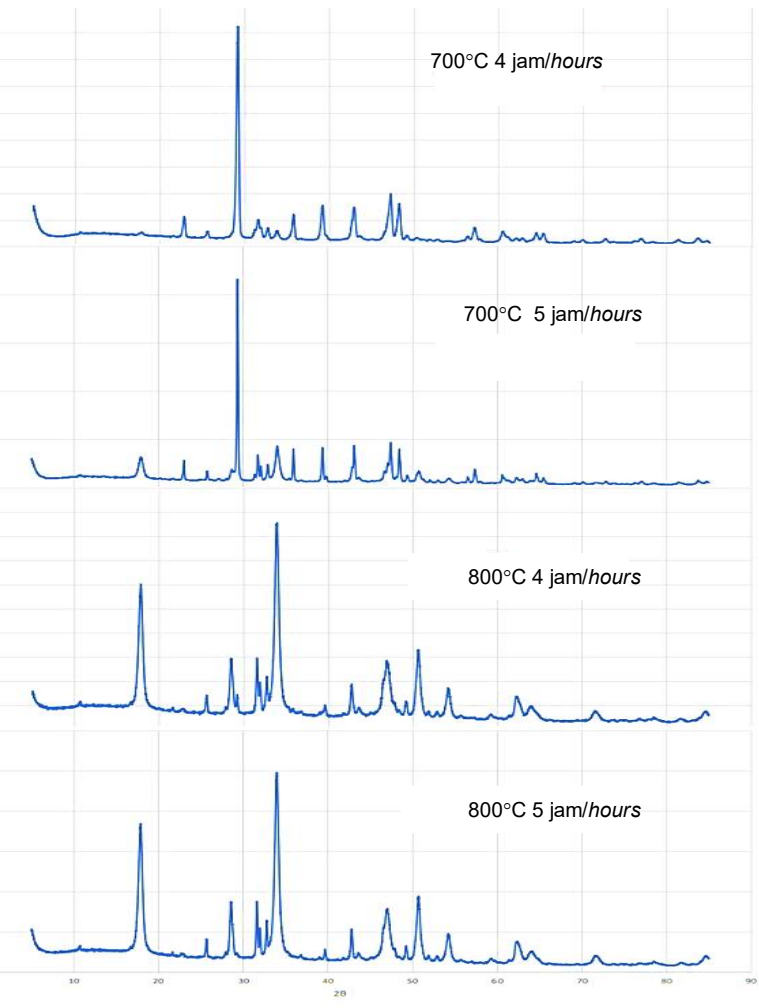

Gambar 4. Hasil analisis kualitatif XRD tepung $\mathrm{CaO}$ Figure 4. Qualitative XRD analysis of $\mathrm{CaO}$ powders 
Tabel 3. Rata-rata derajat kristalinitas tepung $\mathrm{CaO}$ cangkang rajungan Table 3. Crystallinity degree of crab shell $\mathrm{CaO}$ powder

\begin{tabular}{ccc}
\hline \multicolumn{2}{c}{ Kalsinasi/Calcination } & $\begin{array}{c}\text { Derajat Kristalinitas/ } \\
\text { Degree of Crystalinity } \\
\text { Waktu/Time }(\text { Jam/Hours) }\end{array}$ \\
\hline 4 & Suhu/Temperature $\left({ }^{\circ} \mathrm{C}\right)$ & 64.05 \\
5 & 700 & 70.16 \\
4 & 700 & 71.67 \\
5 & 800 & 75.71 \\
\hline
\end{tabular}

sebagai material bahan hidroksiapatit karena menghasilkan derajat kristalinitas di atas 70\% (Rana, Akhtar, Rahman, Jamil, \& Asaduzzaman, 2017). Walaupun demikian, hasil kedua perlakuan tersebut perlu memperhatikan hasil analisa yang lainnya seperti morfologi, gugus fungsi, dan rendemennya.

\section{KESIMPULAN}

Tepung $\mathrm{CaO}$ terbaik dihasilkan dari kalsinasi pada suhu $800^{\circ} \mathrm{C}$ selama 5 jam dengan karakteristik morfologi penampakan yang halus, berkurangnya granula yang tidak seragam, pori yang lebih kecil, kadar kalsium $91,96 \pm 5,07 \%$, serta presentase derajat kristalinitas sebesar $75 \%$. Disarankan untuk dilakukan penelitian lanjutan untuk menaikkan suhu di atas $800^{\circ} \mathrm{C}$, sehingga diperoleh morfologi tepung $\mathrm{CaO}$ yang lebih halus, derajat kristalinitas, dan jumlah massa kalsium yang lebih tinggi sebagai prekursor hidroksiapatit.

\section{UCAPAN TERIMAKASIH}

Penelitian ini dibiayai oleh DIPABBRP2BKP Tahun 2020. Dalam penyusunan makalah ini, Fera Roswita Dewi dan Bagus Hadiwinata bertindak sebagai kontributor utama.

\section{DAFTAR PUSTAKA}

Anitha, P., \& Pandya. H. M. (2014). Synthesis, characterization and antimicrobial Activity of nano hydroxyapatite via sol-gel method. Journal of Nanotechnology Research and Practice. 3(3), 120125.

Badan Standardisasi Nasional (BSN). (2006a). Pengujian Kadar Air pada Produk Perikanan. SNI No. 01-2354.2.2006. Badan Standardisasi Nasional

Badan Standardisasi Nasional (BSN). (2006b). Pengujian Kadar Lemak pada Produk Perikanan. SNI No. 01-2354.3.2006. Badan Standardisasi Nasional.
Badan Standardisasi Nasional (BSN). (2006c). Pengujian Kadar Protein pada Produk Perikanan. SNI No. 01-2354.4.2006. Badan Standardisasi Nasional.

Badan Standardisasi Nasional (BSN). (2010). Pengujian Kadar Abu pada Produk Perikanan. SNI No. 012354.1-2010. Badan Standardisasi Nasional.

Bose, S., Tarafder, S., Edgington, J., \& Bandyopadhyay, A. (2011). Calcium phosphate ceramics in drug delivery. Biomaterials for Regenerative Medicine, 63(4), 93-98. doi: 0.1007/s11837-011-0065-7

Dorozhkin, S. V. (2010). Bioceramics of Calcium Orthophosphates. Biomaterials, 31(7), 1465-85. doi:10.1016/j.biomaterials.2009.11.050.

Handayani, L., Zuhrayani, R., Putri, N., \& Nanda, R. (2020). Pengaruh suhu kalsinasi terhadap nilai rendemen CaO. Jurnal Tilapia, 1(1), 1-6. doi: 10.30601/tilapia.v1i1.1007

Hanura, A. B., Trilaksani, W., \& Suptijah, P. (2017). Karakterisasi nanohidroksiapatit tulang tuna Thunnus sp. sebagai sediaan biomaterial. Jurnal IImu dan Teknologi Kelautan Tropis, 9(2), 619-30. doi: 10.29244/jitkt.v9i2.19296

Harahap, A. W., \& Helwani, Z. (2015). Sintesis hidroksiapatit melalui precipitated calcium carbonate (PC) cangkang kerang darah dengan metode hidrotermal pada variasi $\mathrm{pH}$ dan waktu reaksi.Jurnal Online Mahasiswa Fakultas Teknik Universitas Riau, 2(2), 1-8.

Henggu, K. U., Ibrahim, B., \& Suptijah, P. (2019). Hidroksiapatit dari cangkang sotong sebagai sediaan biomaterial perancah tulang. Jurnal Pengolahan Hasil Perikanan Indonesia, 22(1), 1-13. doi: 10.17844/jphpi.v22i1.25869

Ichsan, R. H. N. A., Helwani, Z., \& Zultiniar. (2015). Sintesis hidroksiapatit melalui precipitated calcium carbonate (PCC) dari cangkang kerang darah dengan metode hidrotermal pada variasi waktu reaksi dan rasio $\mathrm{Ca} / \mathrm{P}$. Jurnal Online Mahasiswa Fakultas Teknik Universitas Riau, 2(2), 1-9.

Kantharia, N., Naik, S., Apte, S., Kheur, M., Kheur, S., \& Kale, B., (2014). Nano-Hydroxyapatite and its contemporary applications. Journal of Dental Research and Scientific Development, 1(1), 15. doi: 10.4103/2348-3407.126135 
Khoirudin, M., Yelmida, \& Zultiniar. (2015). Sintesis dan karakterisasi hidroksiapatit dari kulit kerang darah (Anadara granosa) dengan proses hidrotermal. Jurnal Online Mahasiswa Fakultas Teknik , 2(2), 1-8.

Kolmas, J., Krukowski, S., Laskus, A., \& Jurkitewicz, M. (2016). Synthetic hydroxyapatite in pharmaceutical applications. Ceramics International, 42(2), 2472-87. doi:10.1016/j.ceramint.2015.10.048.

Kurniawan, A., Nizar, M., Rijal, M., Bagas, R., \& Setyarsih, W. (2014). Studi pengaruh variasi suhu kalsinasi terhadap kekerasan bentuk morfologi, dan analisis porositas nanokomposit $\mathrm{CaO} / \mathrm{SiO} 2$ untuk aplikasi bahan biomaterial. Jurnal Penelitian Fisika dan Aplikasinya (JPFA), 4(2), 22. doi: 10.26740/ jpfa.v4n2.p22-26

Kurniawan, A. M., Hartini, S., \& Cahyanti, M. N. (2019). Pengaruh konsentrasi fosfat terhadap Perbandingan $\mathrm{Ca} / \mathrm{P}$ hidroksiapatit dari limbah gipsum industri keramik. EKSAKTA, 19(1), 46-56.

Kusumaningrum, I., Sutono, D., \& Pamungkas, B. F. (2016). Pemanfaatan tulang ikan belida sebagai tepung sumber kalsium dengan metode alkali. Jurnal Pengolahan Hasil Perikanan Indonesia, 19(2), 148155. doi: 10.17844/jphpi.2016.19.2.148

Landi, E., Tampieri, A., Celotti, G. \& Spriro, S. (2000). Densification behaviourand mechanisms of synthetic hydroxyapatite. Journal of European Ceramics Society.

Lubena, L., Naidir, F., Andrian, B., \& Sandi, A. D. (2020). Penurunan Turbidity, $\mathrm{PH}$, Kadar Fe Menggunakan Biokoagulan Kitosan Dari Cangkang Rajungan (Portunus pelagicus). Jurnal Konversi, 9(1), 7-16. doi:10.24853/konversi.9.1.10

Negara, I. M. S., \& Simpen, I. M. (2018). Karakteristik hidroksiapatit hasil ekstraksi termal dari tulang limbah dan aplikasinya untuk adsorpsi ion selektif biru metilen. Cakra Kimia, 6(2), 123-30.

Ngapa, Y. D. (2018). Sintesis dan karakterisasi hidroksiapatit ( HAp ) dari limbah dengan metode basah presipitasi. Jurnal Dinamika Sains, 2(1), 67-72.

Purwasasmita, B., \& Gultom, R. S. (2008). Sintesis dan karakterisasi serbuk hidroksiapatit skala sub mikron menggunakan metode presipitasi. Jurnal Bionatura, 10(2), 155-67.

Puspita, F. W., \& Cahyaningrum, S. E. (2017). Sintesis dan karakterisasi hidroksiapatit dari cangkang telur ayam ras (Gallus gallus) menggunakan metode pengendapan basah.UNESA Journal of Chemistry, 6(2), 100-106.
Rana, M., Akhtar, M., Rahman, S., Jamil, H. M., \& Asaduzzaman, S. (2017). Extraction of hydroxyapatite from bovine and human cortical bone by thermal decomposition and effect of gamma radiation: a comparative study. International Journal of Complementary \& Alternative Medicine, 8(3). doi: 10.15406/ijcam.2017.08.00263

Raya, I., Mayasari, E., Yahya, A., Syahrul, M., \& Latunra, A. I. (2015). Shynthesis and characterizations of calcium hydroxyapatite derived from crabs shells ( Portunus pelagicus ) and its potency in safeguard against to dental demineralizations. International Journal of Biomaterials, 2015. doi: 10.1155/2015/469176

Riyanto, B., \& Maddu, A. 2014. Material of HydroxyapatiteBased Bioceramics from Tuna Fishbone. Jurnal Pengolahan Hasil Perikanan Indonesia, 16(2). 119-32.

Rizkayanti, Y., \& Yusuf, Y. (2019). Optimization of the temperature synthesis of hydroxyapatite from Indonesian crab shells, International Journal of Nanoelectronics and Materials, 12(1), 85-92.

Rosalina, W, Pascawinata, A., \& Roesnoer, M. (2017). Karakteristik scaffold hidroksiapatit dari gigi manusia menggunakan uji X-Ray Diffraction (XRD). Jurnal BDent., 4(2),133-40.

Setiawan, M. A. (2016). Studi Variasi Ukuran Butir Proses Desulfurisasi Kokas Petroleum Yang Terkalsinasi. Tugas Akhir. Program Studi Teknik Material dan Metalurgi: Institut Teknologi Sepuluh November

Suharto, S., Romadhon, \& Redjeki, S. (2016). Analisis Susut Bobot Pengukusan Dan Rendaman Pengupasan Rajungan Berukuran Berbeda Dan rajungan bertelur. Fisheries Science and Technology (IJFST), 12(1), 47-51. doi: 10.14710/ijfst.12.1.47-51

Sunardi, Irawati, U., \& Wianto, T. (2011). Karakterisasi kaolin lokal Kalimantan Selatan hasil kalsinasi. Jurnal Fisika FLUX, 8, 59-65.

Supangat, D., \& Cahyaningrum, S. E. (2017). Sintesis dan karakterisasi hidroksiapatit dari cangkang kepiting (Scylla serrata) dengan metode pengendapan basah. UNESA Journal of Chemistry, 6(3),143-49.

Warastuti, Y., \& Abbas, B. (2011). Sintesis dan karakterisasi pasta injectable bone substitute Iradiasi berbasis hidroksiapatit. A Scientific Journal for The Applications of sotopes and Radiation, 7(2), 73-82.

Yang, Y., Wu, Q., Wang, M., Long, J., Mao, Z., \& Chen, X. (2014). Hydrothermal synthesis of hydroxyapatite with different morphologies: influence of supersaturation of the reaction system. Crystal Growth \& Design, 14(9). doi: $10.1021 / \operatorname{cg} 501063 \mathrm{j}$ 